\title{
Accumulation and effects of cyanobacterial microcystins and anatoxin-a on benthic larvae of Chironomus spp. (Diptera: Chironomidae)
}

\author{
Magdalena TOPOROWSKA ${ }^{1}$, Barbara PAWLIK-SKOWROŃSKA ${ }^{1,2}$ and Renata KALINOWSKA ${ }^{2}$ \\ ${ }^{1}$ Department of Hydrobiology, University of Life Sciences in Lublin, Akademicka 13, 20-950 Lublin, Poland; \\ e-mails: magdalena.toporowska@up.lublin.pl; pawlik@poczta.umcs.lublin.pl \\ ${ }^{2}$ Centre for Ecological Research, P.A.S, Experimental Station, Niecała 18, 20-080 Lublin, Poland; \\ e-mail: renata_kalinowska@tlen.pl
}

Key words. Diptera, Chironomidae, Chironomus larvae, Planktothrix, Anabaena, Dolichospermum, Cuspidothrix, cyanotoxins, cyanotoxin accumulation, hypertrophic lake

\begin{abstract}
Larvae of Chironomidae are distributed world-wide and are very abundant in eutrophic water bodies affected by cyanobacterial blooms. However, there is little information on the effect of cyanobacteria and their metabolites on these aquatic organisms. Our studies revealed that benthic species of Chironomus inhabiting a hypertrophic lake where blooms of microcystin (MC) and/or anatoxin-a (ANTX)-producing filamentous Planktothrix agardhii, Dolichospermum spp. and Cuspidothrix issat-

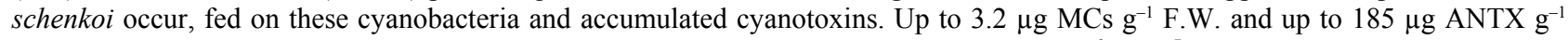
F.W. were detected. Of the four MC variants detected in the cyanobacterial biomass [Asp ${ }^{3}, \mathrm{Dhb}^{7}$ ]MC-RR and MC-LR prevailed, whereas in the larvae it was $\left[\mathrm{Asp}^{3}, \mathrm{Dhb}^{7}\right] \mathrm{MC}-\mathrm{RR}$ and MC-LA. The effect of pure MC-LR and ANTX as well as crude extracts of MC-producing P. agardhii and ANTX-producing D. lemmermannii on lake and riverine larvae of Chironomus spp. was also compared. The assays revealed that pure cyanotoxins (concentrations: $0.83-3.32 \mathrm{mg} \mathrm{L}^{-1}$ ) were generally less toxic to riverine larvae than cyanobacterial extracts containing approximately 10 -times less toxins. The survival of both the lake and riverine Chironomus larvae did not decrease when exposed to environmentally relevant concentrations of cyanotoxins $\left(<0.20 \mathrm{mg} \mathrm{L}^{-1}\right)$. The larvae were also highly resistant to higher amounts (up to $0.35 \mathrm{mg} \mathrm{ANTX} \mathrm{L}^{-1}$ and $0.42 \mathrm{mg} \mathrm{MCs} \mathrm{L}^{-1}$ ) of extracellular toxins. In the natural environment, Chironomus larvae exposed to toxins contained in cyanobacterial prey, dissolved in water and/or bound to bottom sediments may be very important vectors of cyanotoxins to higher levels in aquatic food chains. To the best of our knowledge, this is the first report on the accumulation of ANTX and effects of cyanotoxins on Chironomus larvae.
\end{abstract}

\section{INTRODUCITON}

Water blooms formed by cyanobacteria that produce various toxins, such as hepatotoxic microcystins (MCs), neurotoxic anatoxin-a (ANTX) etc. (Carmichael, 1992; Welker \& Döhren, 2006), which may affect aquatic organisms at various levels in the food chain (FerrãoFilho \& Kozlowsky-Suzuki, 2011). The sensitivity of hydrobionts to exposure to cyanotoxins differs greatly. There is little information on the effect of cyanobacterial toxins on benthic insect larvae, such as Chironomus spp., which are widespread and abundant in eutrophic water bodies (Armiatge et al., 1995; Frouz et al., 2003; Chen \& Xie, 2008). Larvae of Chironomidae play an important role in aquatic ecosystems, e.g. as a prey of fish, and are good indicators of water quality (Armiatge et al., 1995).

Toxin-producing cyanobacteria develop abundantly in the pelagic zone (Sivonen et al., 1990; PawlikSkowrońska et al., 2008), but may also form mats (e.g. Oscillatoria limosa At. ex Gom. and Oscillatoria tenuis C. Agardh) on the bottom of various water bodies (Mez et al., 1997). Planktonic species, like the microcystinproducing Planktothrix agardhii (Gom.) Anagn. et Kom., Microcystis spp. and Dolichospermum spp. (syn. Anabaena), which may produce both MCs and ANTX, overwinter on bottom sediments (Hašler et al., 2004). As a consequence, MCs, ANTX and other cyanotoxins bind to lake sediments (Pawlik-Skowrońska et al., 2010; Klitzke et al., 2011), particularly to the upper layers, where they may affect the benthic fauna. Currently little is known about the accumulation and influence of cyanotoxins on benthic macro-invertebrates (Kotak et al., 1996; Chen \& Xie, 2008; Ibelings \& Havens, 2008), in particular, the consequences of exposing the aquatic fauna to ANTX. There are several reports that exposure of fish to ANTX in the laboratory (Oberemm et al., 1999; Osswald et al. 2007) and under natural (Pawlik-Skowrońska et al., 2012) conditions results in it accumulating and damaging the tissue of edible fish. There is no information on ANTX accumulation and effect of cyanotoxins on benthic larvae of Chironomus spp. As chironomids are non-selective feeders (Ali, 1990) cyanobacteria (including potential toxin-producers, like Anabaena, Oscillatoria, Lyngbya and Microcystis) are an essential source of food for the larvae. For example, cyanobacteria are predominant (52-84\% of food) in guts of larvae of Chironomus crassicaudatus Malloch living in a lake in Florida (Ali, 1990). Therefore, in eutrophic waters where cyanobacterial blooms occur, there is the possibility that cyanotoxins will be in the trophic chain and are potential hazard for fish and their consumers.

We hypothesized that Chironomus larvae inhabiting water bodies affected by perennial blooms of toxigenic 
cyanobacteria accumulate and are tolerant of cyanotoxins. The effects of MCs and ANTX on lake and riverine populations of Chironomus were experimentally compared.

\section{MATERIAL AND METHODS}

\section{Study area, sampling and analysis of cyanobacteria}

This study was carried out in the shallow flow-through Lake Syczyńskie (E. Poland) in which perennial blooms of toxigenic cyanobacteria occur (Pawlik-Skowrońska et al., 2008; Toporowska et al., 2010). Water samples for chemical analyses and for qualitative and quantitative analyses of cyanobacteria and cyanotoxins were collected from the uppermost $(0-0.5 \mathrm{~m})$ and near-bottom (2.4-2.8 m) water layers once a month (April-November) in 2008. The biomass of cyanobacteria was based on counts and measurement of algae obtained using an inverted microscope (Utermöhl, 1958). For cyanobacteria with straight filaments, a length of $100 \mu \mathrm{m}$ was counted as one individual. One coil of coiled Dolichospermum spp. (syn. Anabaena) and one colony of coccoid cyanobacteria were recognised as individuals. The taxonomic identification was carried out mostly following Komárek (1996), Komárek \& Anagnostidis (2005) and Wacklin et al. (2009).

\section{Organisms}

Chironomus larvae were collected by means of a hand net (diameter of $40 \mathrm{~cm}$ and mesh size of $250 \mu \mathrm{m}$ ) from Lake Syczyńskie 5 times (from April to October) in 2008. Larvae were separated in a laboratory and stored in organic sediments (temp. $3-4{ }^{\circ} \mathrm{C}$ ) until used in the toxicological experiments. In toxicological experiments, Chironomus larvae (commercially available) collected from River Przemsza (S. Poland) were also used. The nomenclature of Chironomidae larvae followed Wiederholm (1983). Both the lake and riverine organisms were over 20 mm long.

Lake larvae for cyanotoxin analyses weighed from $0.08-5.28$ g F.W. and were frozen $\left(-20^{\circ} \mathrm{C}\right)$ until the day of toxin extraction. Photographic documentation of the gut contents of the lake Chironomus sp. was done using a camera mounted on a light microscope.

\section{Physical-chemical analyses}

The physical-chemical parameters of the water in the uppermost and bottom layers of the lake were measured once a month. Biogenic nutrients were determined according to Golterman (1971) and chlorophyll-a according to PN-ISO 10260 (2000). The Carlson Trophic State Index (TSI), based on water transparency measurements (Secchi disc), was calculated according to Carlson (1977).

\section{Cyanotoxin extraction}

For the determination of intra- and extracellular MCs and ANTX, 0.5-1.0 L of lake water was filtered through Whatman $\mathrm{GF} / \mathrm{C}$ filters, and extracts of the filtered off phytoplankton were prepared using ultrasonication ( 3 times for $5 \mathrm{~min}, 50 \mathrm{~W}$, ultrasonic homogeniser Sonoplus, Bandelin) in $75 \%(\mathrm{v} / \mathrm{v})$ methanol (Merck, pure p.a.) containing $0.002 \mathrm{M} \mathrm{HCl}$. After centrifugation $\left(14,000 \mathrm{rpm}\right.$ for $\left.10 \mathrm{~min}, 17^{\circ} \mathrm{C}\right)$, supernatants were collected and frozen $\left(-20^{\circ} \mathrm{C}\right)$ until required for cyanotoxin analysis. Crude extracts of the scum of Planktothrix agardhii and Dolichospermum lemmermannii Richt. in Lemm. (collected in the lake) were prepared using ultrasonication ( 3 times for $5 \mathrm{~min}$ ). After centrifugation, supernatants were frozen $\left(-20^{\circ} \mathrm{C}\right)$. Chironomus larvae were first homogenised in acidified $75 \%(\mathrm{v} / \mathrm{v})$ methanol (Merck, pure p.a.) and then ultrasonicated (2 times for $5 \mathrm{~min}$ ). After centrifugation $\left(14,000 \mathrm{rpm}\right.$ for $\left.10 \mathrm{~min}, 17^{\circ} \mathrm{C}\right)$, super- natants were collected and purified with n-hexane $(1: 1, \mathrm{v} / \mathrm{v})$ and then frozen.

\section{HPLC-DAD analysis of microcystins}

The HPLC-photodiode array detection system (Shimadzu) was used for microcystin detection and identification. The detection range was 200-300 nm. MC-LR, -RR, -YR, -LA, -LY, - LW, -LF, -WR (Alexis) were used as standards. Extracts were separated using acetonitrile (Merck) acidified with $0.05 \%$ trifluoroacetic acid (gradient $30-100 \%$ ) at a flow rate of 0.7 $\mathrm{ml} / \mathrm{min}$ in a RP-18 Purosphere column $(125 \times 3 \mathrm{~mm}$, Merck).

\section{HPLC-FLD analysis of anatoxin-a}

ANTX in extracts of cyanobacteria and Chironomus was determined using liquid chromatography (HPLC, Beckman) with fluorescence detection (Shimadzu) according to James et al. (1998) and Furey et al. (2005). For ANTX derivatization, $10 \%$ NBD-F (4-fluoro-7-nitrobenzofuran; Fluka) was used. The detector parameters were as follows: excitation wavelength 470 $\mathrm{nm}$ and emission wavelength $530 \mathrm{~nm}$. Extract separation was obtained using a RP-18 Purosphere column $(125 \times 3 \mathrm{~mm}$, Merck) and TFA $(0.05 \%)$ acidified acetonitrile at a flow rate of $0.6 \mathrm{ml} / \mathrm{min}$. For identification and quantitative determinations, standard ANTX (Tocris, Bioscence) was used.

\section{Toxicological experiments}

Toxicity of MC-LR and ANTX standards and extracts of cyanobacterial scum containing MCs or ANTX, for larvae of Chironomus spp. indigenous to Lake Syczyńskie and those collected from a river was evaluated using 48- and 96-h bioassays. The survival of larvae exposed to cyanotoxins was estimated. The death of organisms was verified by touching them with tweezers. Series of three dilutions of cyanotoxin standards (0.83-3.32 $\left.\mathrm{mg} \mathrm{L}^{-1}\right)$, three dilutions of crude extract of $P$. agardhii $\left(0.11-0.91 \mathrm{mg} \mathrm{MCs} \mathrm{L}^{-1}\right)$ and four dilutions of the crude extract of D. lemmermannii (0.06-0.35 mg ANTX $\left.\mathrm{L}^{-1}\right)$ were prepared in standard freshwater. The assays were performed twice, each time in three replicates in darkness, at room temperature $\left(20 \pm 1^{\circ} \mathrm{C}\right)$. Due to the low number of larvae from Lake Syczyńskie, the assays were only done using extracts of cyanobacteria. The influence of $1 \%$ methanol (the maximum concentration of the solvent for MC-LR) on the survival of lake and riverine larvae was also determined and no effect was observed.

\section{RESULTS}

\section{Bloom-forming cyanobacteria and cyanotoxin production}

In the shallow hypertrophic $\left(\mathrm{TSI}_{\mathrm{SD}}=65-82\right)$ lake, the physical-chemical conditions supporting mass development of cyanobacteria were similar at the surface and the near-bottom of the lake (Table 1). The vertical distribution of cyanobacteria and oxygen concentration in the lake water were also homogenous. The seasonal average values of the total biomass of cyanobacteria ranged from $1.2 \mathrm{mg} \mathrm{L}^{-1}$ in spring to $92.9 \mathrm{mg} \mathrm{L}^{-1}$ in autumn (the maximum exceeded $100 \mathrm{mg} \mathrm{L}^{-1}$ ). In spring, ANTXproducing Nostocales with filamentous Dolichospermum cf. heterosporum (Nyg.), D. flos-aquae (Lyng.) Breb. ex Born. et Flath., D. vigueri Denis et Frémy and Aphanizomenon gracile (Lemm.) Lemm. predominated (making up $59 \%, 5 \%, 5 \%$ and $26 \%$, respectively, of the total biomass of Nostocales). Cuspidothrix (syn. Aphanizomenon) issatschenkoi (Usachev) Rajaniemi was present in the lake in spring and summer, but in low quantities (up to 
$0.22 \mathrm{mg} \mathrm{L}^{-1}$ ). In other seasons, the Nostocales biomass was smaller than that of Oscillatoriales, which consisted mainly of Planktothrix agardhii, the main bloom-forming and microcystin-producing species. The total biomass of coccoid Chrooccocales [predominately the non-toxic Aphanocapsa incerta (Lemm.) Cronb. et Kom., A. holsatica (Lemm.) Cronb. et Kom. and potentially toxic Microcystis aeruginosa (Kütz.)] was the lowest among the cyanobacteria (Table 1).

The concentrations of cyanotoxins (MCs and ANTX) in the lake were similar in the surface and bottom water layers (Fig. 1). The average seasonal concentrations of intracellular MCs increased from $1.22 \mu \mathrm{g} \mathrm{L}^{-1}$ in spring to 17.23 in summer and $56.78 \mu \mathrm{g} \mathrm{L}^{-1}$ in autumn (Fig. 1A). Extracellular forms were present in much lower concentrations $\left(0.16-2.18 \mu \mathrm{g} \mathrm{L}^{-1}\right)$. The desmethyl derivative of $\mathrm{MC}-\mathrm{RR}$ - $\left[\mathrm{Asp}^{3}, \mathrm{Dhb}^{7}\right] \mathrm{MC}-\mathrm{RR}$ predominated (91.9$-96.2 \%)$ in the total concentration of cell-bound MCs. However, MC-LR > MC-LA > MC-YR were also detected (Table 2). Average seasonal concentrations of intracellular ANTX in the lake water changed over a narrower range: $1.51-2.71 \mu \mathrm{g} \mathrm{L}^{-1}$ (Fig. 1B). The cyanotoxin was only detected in spring and summer during mass development of Nostocales. Extracellular ANTX concentration reached up to $1.73 \mu \mathrm{g} \mathrm{L}^{-1}$ at the same time. In April, when Dolichospermum spp. formed a water bloom,
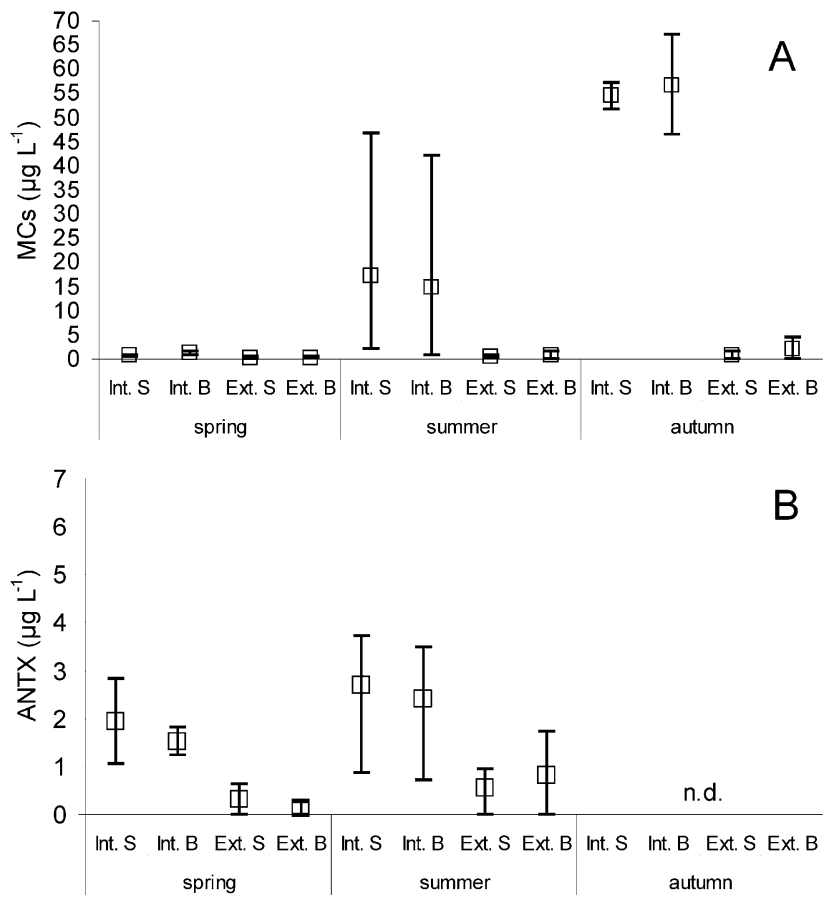

Fig. 1. Distribution of intra- (Int.) and extracellular (Ext.) microcystins (A) and anatoxin-a (B) in the surface (S) and bottom (B) layers of water in Lake Syczyńskie (seasonal mean values; $n=2-3$, and range of values). n.d. - not detected.

TABLE. 1. Physical-chemical and biological characteristics of the surface (S) and bottom (B) layers of water in Lake Syczyńskie (seasonal mean values) in 2008 .

\begin{tabular}{|c|c|c|c|c|}
\hline Parameters & Water layer & Spring & Summer & Autumn \\
\hline \multirow[b]{2}{*}{ Water temperature $\left({ }^{\circ} \mathrm{C}\right)$} & $\mathrm{S}$ & 18.4 & 21.6 & 9.9 \\
\hline & $\mathrm{B}$ & 17.5 & 21.0 & 10.0 \\
\hline \multirow{2}{*}{$\mathrm{pH}$} & $\mathrm{S}$ & 8.1 & 8.1 & 7.8 \\
\hline & $\mathrm{B}$ & 8.0 & 8.1 & 7.8 \\
\hline \multirow{2}{*}{ Conductivity $\left(\mu \mathrm{S} \mathrm{cm}^{-1}\right)$} & $\mathrm{S}$ & 560 & 331 & 385 \\
\hline & $\mathrm{B}$ & 564 & 344 & 390 \\
\hline \multirow{2}{*}{$\mathrm{N}-\mathrm{NH}_{4}\left(\mathrm{mg} \mathrm{L}^{-1}\right)$} & $\mathrm{S}$ & 0.182 & 0.316 & 0.509 \\
\hline & $\mathrm{B}$ & 0.221 & 0.324 & 0.540 \\
\hline \multirow{2}{*}{$\mathrm{N}-\mathrm{NO}_{3}\left(\mathrm{mg} \mathrm{L}^{-1}\right)$} & S & 0.030 & 0.064 & 0.196 \\
\hline & $\mathrm{B}$ & 0.029 & 0.068 & 0.269 \\
\hline \multirow{2}{*}{$\mathrm{P}_{-} \mathrm{PO}_{4}\left(\mathrm{mg} \mathrm{L}^{-1}\right)$} & S & 0.021 & 0.022 & 0.093 \\
\hline & $\mathrm{B}$ & 0.025 & 0.022 & 0.096 \\
\hline \multirow{2}{*}{ Oxygen concentration $\left(\mathrm{mg} \mathrm{L}^{-1}\right)$} & $\mathrm{S}$ & 12.5 & 10.4 & 14.2 \\
\hline & $\mathrm{B}$ & 12.3 & 9.4 & 14.2 \\
\hline Transparency - SD (m) & & 0.70 & 0.40 & 0.22 \\
\hline \multirow{2}{*}{ Chlorophyll-a $\left(\mu \mathrm{g} \mathrm{L}^{-1}\right)$} & $\mathrm{S}$ & 51.3 & 202.3 & 237.8 \\
\hline & B & 48.9 & 197.2 & 224.6 \\
\hline \multirow{2}{*}{ Chroococcales biomass (mg L $\left.{ }^{-1}\right)$} & $S$ & 0.15 & 0.36 & 2.46 \\
\hline & $\mathrm{B}$ & 0.19 & 0.27 & 2.92 \\
\hline \multirow{2}{*}{ Nostocales biomass $\left(\mathrm{mg} \mathrm{L}^{-1}\right)$} & $\mathrm{S}$ & 0.95 & 4.17 & 0.04 \\
\hline & $\mathrm{B}$ & 0.88 & 4.38 & 0.01 \\
\hline \multirow{2}{*}{ Oscillatoriales biomass $\left(\mathrm{mg} \mathrm{L}^{-1}\right)$} & $S$ & 0.06 & 27.13 & 90.40 \\
\hline & $\mathrm{B}$ & 0.65 & 27.70 & 84.47 \\
\hline $\mathrm{TSI}_{\mathrm{SD}}$ & & 65 & 73 & 82 \\
\hline
\end{tabular}

${ }^{\mathrm{a}}$ Content of MCs in lake sediments (1-7

$\mathrm{cm}$ ) in 2005 ( $\mu$ g eq. MC-LR g ${ }^{-1}$ D.W.)

$0.91(1 \mathrm{~cm})-0.13(7 \mathrm{~cm})$

a - following Pawlik-Skowrońska et al., 2010. Contribution of different taxa of cyanobacteria to the total biomass $\geq 5 \%$; Chroococcales: Aphanocapsa spp., Microcystis aeruginosa; Nostocales: Dolichospermum spp., Aphanizomenon gracile; Oscillatoriales: Planktothrix agardhii, Planktolyngbya limnetica. 

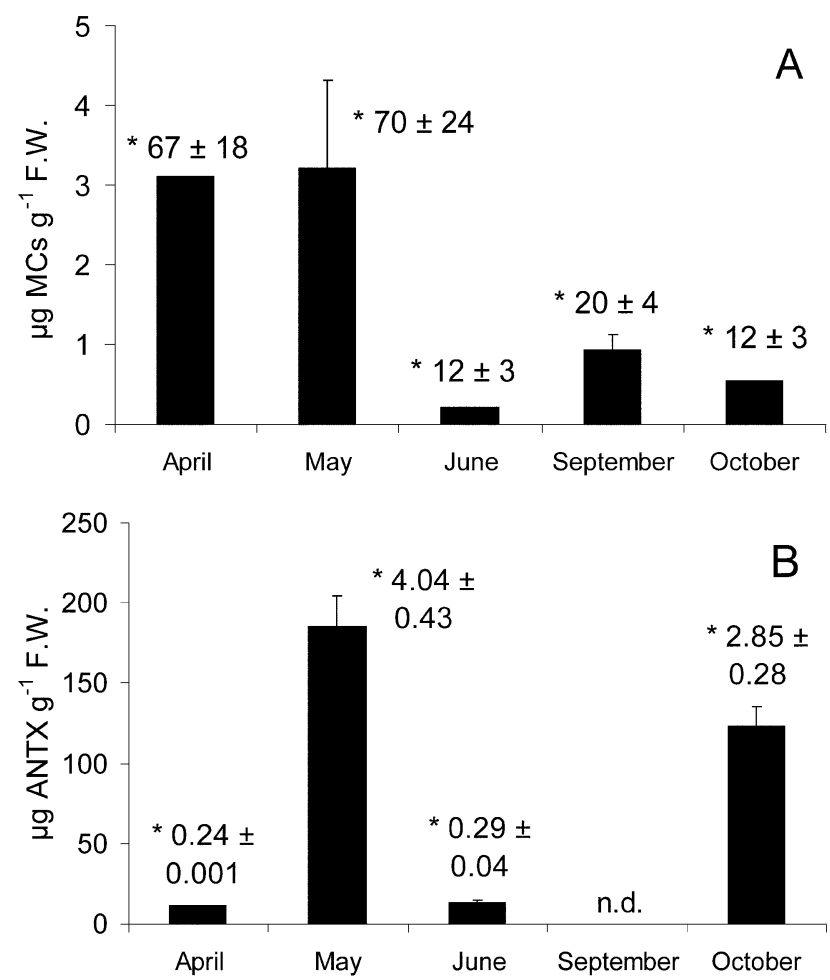

Fig. 2. Contents of microcystins (A) and anatoxin-a (B) in Chironomus sp. larvae collected in Lake Syczyńskie (mean values $\pm \mathrm{SD}, \mathrm{n}=2-3){ }^{*}-$ content of MCs $(\mathrm{ng})$ and ANTX $(\mu \mathrm{g})$ per individual. n.d. - not determined.

the surface scum mostly consisting (98\%) of $D$. flosaquae contained $439 \mu \mathrm{g}$ ANTX L ${ }^{-1}$. The benthic cyanobacteria Oscillatoria limosa, common in the lake, also produced MCs and there was $189 \mu \mathrm{g} \mathrm{MCs} \mathrm{L}^{-1}$ in the benthic mat.

\section{Cyanotoxins in the Chironomus larvae from the lake}

As a consequence of long-term cyanobacterial blooms, their relatively homogenous distribution in the water column and simultaneous occurrence of MCs and ANTX in the surface and near-bottom water layers, both cyanotoxins occurred in the Chironomus larvae inhabiting the lake (Fig. 2). The filaments of $P$. agardhii and $O$. limosa were found in guts of lake larvae (Fig. 3). Microcystins' and anatoxins' accumulation were found in larvae collected throughout the study period and a higher content of ANTX than MCs was detected. The highest content of MCs in Chironomus sp. (Fig. 2A) was found in spring

TABLE 2. The percentage of the different variants of microcystins identified in the cyanobacterial biomass collected from August to November.

\begin{tabular}{ccccc}
\hline \multirow{2}{*}{ Month } & \multicolumn{4}{c}{ MC variants } \\
\cline { 2 - 5 } & $\begin{array}{c}\left.\mathrm{Asp}^{3}, \mathrm{Dhb}^{7}\right] \\
\mathrm{MC}^{2} \mathrm{RR}\end{array}$ & MC-LR & MC-LA & MC-YR \\
\hline VIII & 90.6 & 4.0 & 3.8 & 1.6 \\
IX & 94.4 & 4.1 & 0 & 1.5 \\
X & 96.2 & 3.8 & 0 & 0 \\
XI & 91.9 & 8.1 & 0 & 0 \\
\hline
\end{tabular}

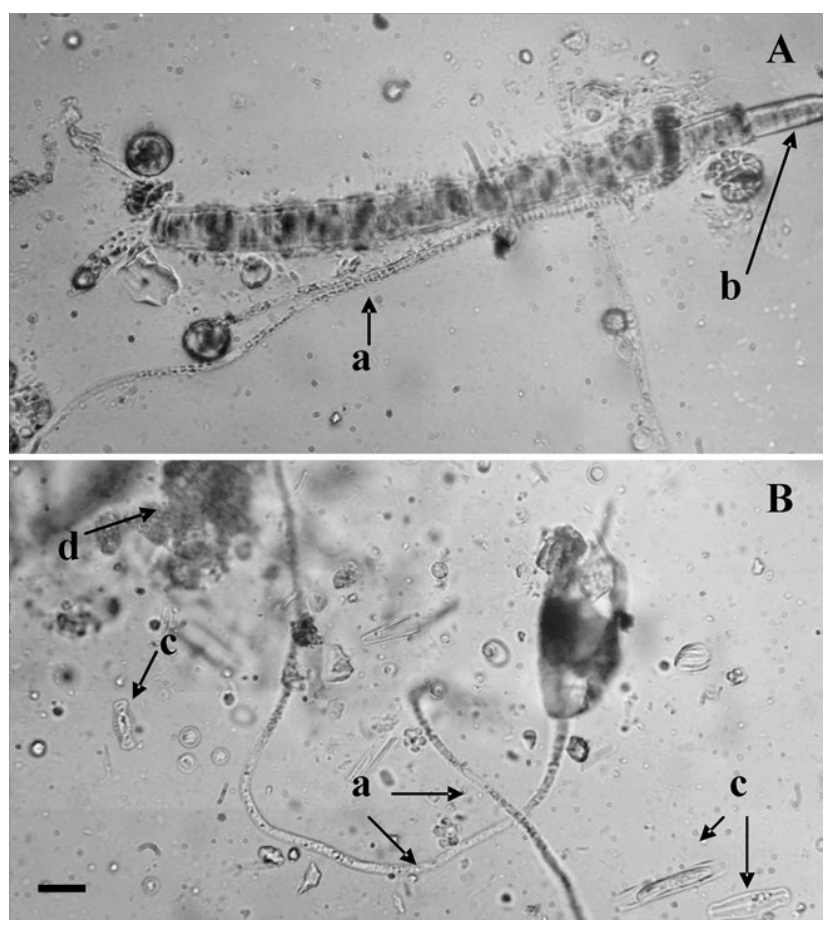

Fig. 3. The contents (A-B) of guts of Chironomus sp. inhabiting Lake Syczyńskie: cyanobacteria $\mathrm{a}-P$. agardhii, $\mathrm{b}-O$. limosa; c-diatoms; d-detritus. Scale $=10 \mu \mathrm{m}$.

(3.2 $\mu \mathrm{g} \mathrm{g} \mathrm{g}^{-1}$ F.W. of larvae; 70 ng per organism) during a multispecies bloom of cyanobacteria (mainly Nostocales). In summer and autumn (during a bloom mainly formed by MC-producing P. agardhii), it decreased to $0.21-0.93$ $\mu \mathrm{g} \mathrm{g}^{-1}$ F.W. of Chironomus sp. The desmethyl derivative of MC-RR (66-100\%) and MC-LA (34\%) were detected in the larvae. The highest content of ANTX (Fig. 2B; $185.4 \mu \mathrm{g} \mathrm{g}^{-1}$ F.W.; $4.04 \mu \mathrm{g}$ per organism) was found in larvae collected in May in the littoral zone, where two weeks earlier a surface scum of ANTX-producing $D$. flosaquae occurred.

\section{Effect of cyanotoxins on Chironomus larvae}

To estimate the direct influence of cyanotoxins on Chironomus larvae, pure standards of MC-LR and ANTX and the extracellular toxins present in crude extracts of cyanobacteria were tested. The experiments carried out on the lake and riverine larvae of Chironomus sp. revealed that pure MC-LR was slightly more toxic than ANTX to the riverine larvae (Figs 4A, 5A). MC-LR at the highest concentration used $\left(3.32 \mathrm{mg} \mathrm{L}^{-1}\right)$ after $96 \mathrm{~h}$ of exposure caused a decrease in the survival of riverine larvae to approximately $61 \%$, whereas ANTX under the same conditions caused a decrease to approximately $83 \%$ in comparison with the controls. The cyanobacterial extracts containing approximately 10-times less MCs or ANTX (Figs 4B, C, 5B, C) were more toxic than standard cyanotoxins for the lake and riverine Chironomus spp. The crude extract of D. lemmermannii (Figs 5B, C), containing ANTX, seemed to be slightly more toxic for the lake and riverine larvae than that of MCs-containing P. agardhii (Figs 4B, C), at very similar cyanotoxin concentrations $\left(0.11-0.35 \mathrm{mg} \mathrm{L}^{-1}\right)$. However, in the extract of 

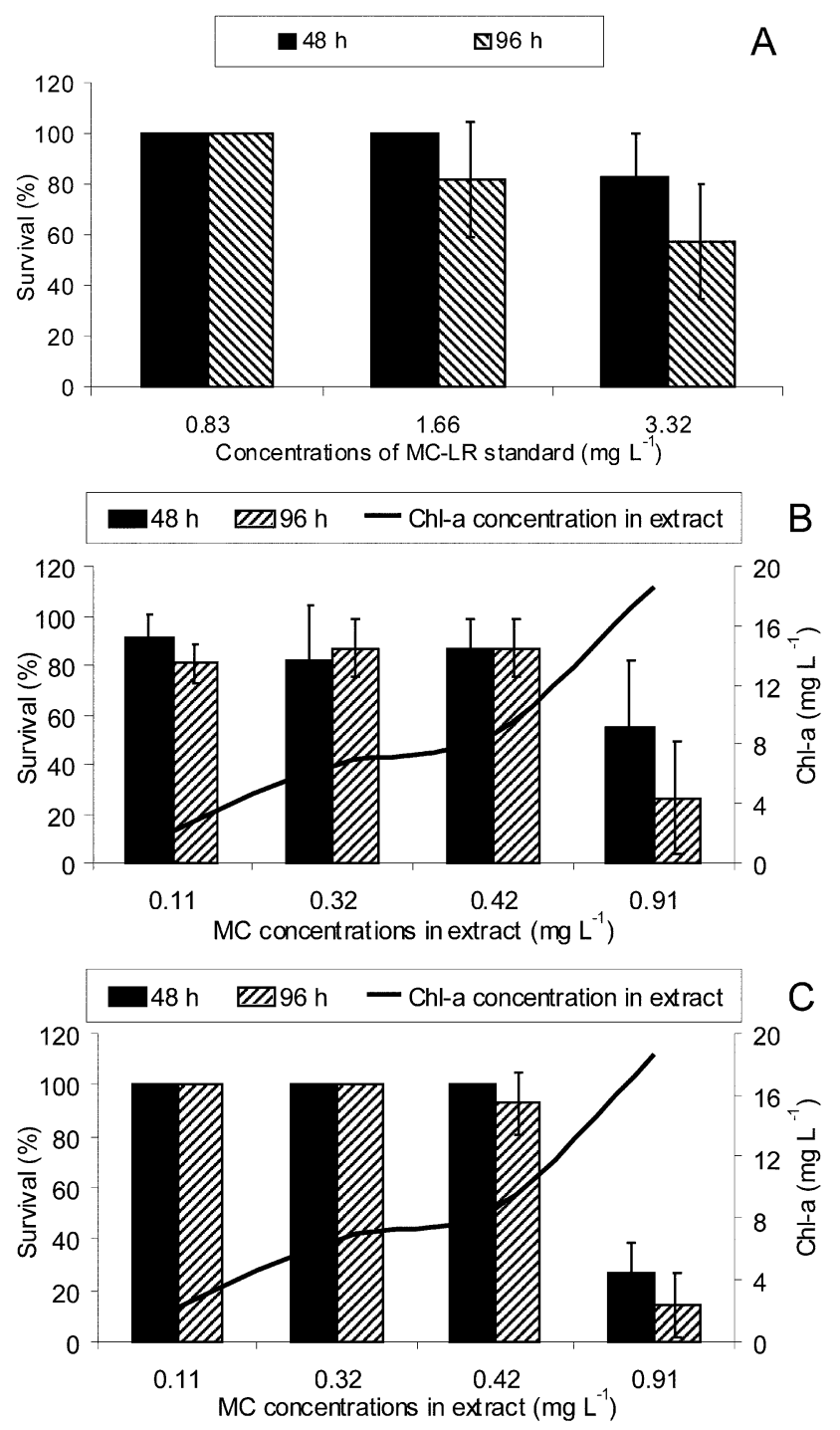

Fig. 4. Influence of pure MC-LR (A) and $P$. agardhii extract containing different concentrations of MCs (B and C) on survival of Chironomus spp. larvae after 48 and $96 \mathrm{~h}$ of exposure (mean values $\pm \mathrm{SD} ; \mathrm{n}=6$ ). Survival of organisms in controls was set as $100 \%$. A, B - riverine larvae, $\mathrm{C}$ - lake larvae.

D. lemmermannii containing $0.35 \mathrm{mg}$ ANTX $\mathrm{L}^{-1}$, there was a higher concentration of chlorophyll-a $\left(12 \mathrm{mg} \mathrm{L}^{-1}\right)$ than in the $P$. agardhii extract $\left(7 \mathrm{mg} \mathrm{L}^{-1}\right)$. This was a consequence of extracting a greater biomass of $D$. lemmermannii in order to obtain a similar cyanotoxin concentration. This possibly accounts for the different contents of other, unidentified cyanobacterial metabolites. There was no clear difference between the response of lake and riverine Chironomus larvae to the same cyanobacterial extracts, despite the greater accumulations of cyanotoxins in the larvae from the lake.

\section{DISCUSSION}

Despite the extensive studies on cyanobacterial metabolites (Carmichael, 1992; Welker \& Döhren, 2006) and their influence on living organisms (Ibelings \& Havens, 2008; Ferrão-Filho \& Kozlowsky-Suzuki, 2011), there is little information on their accumulation and effects on
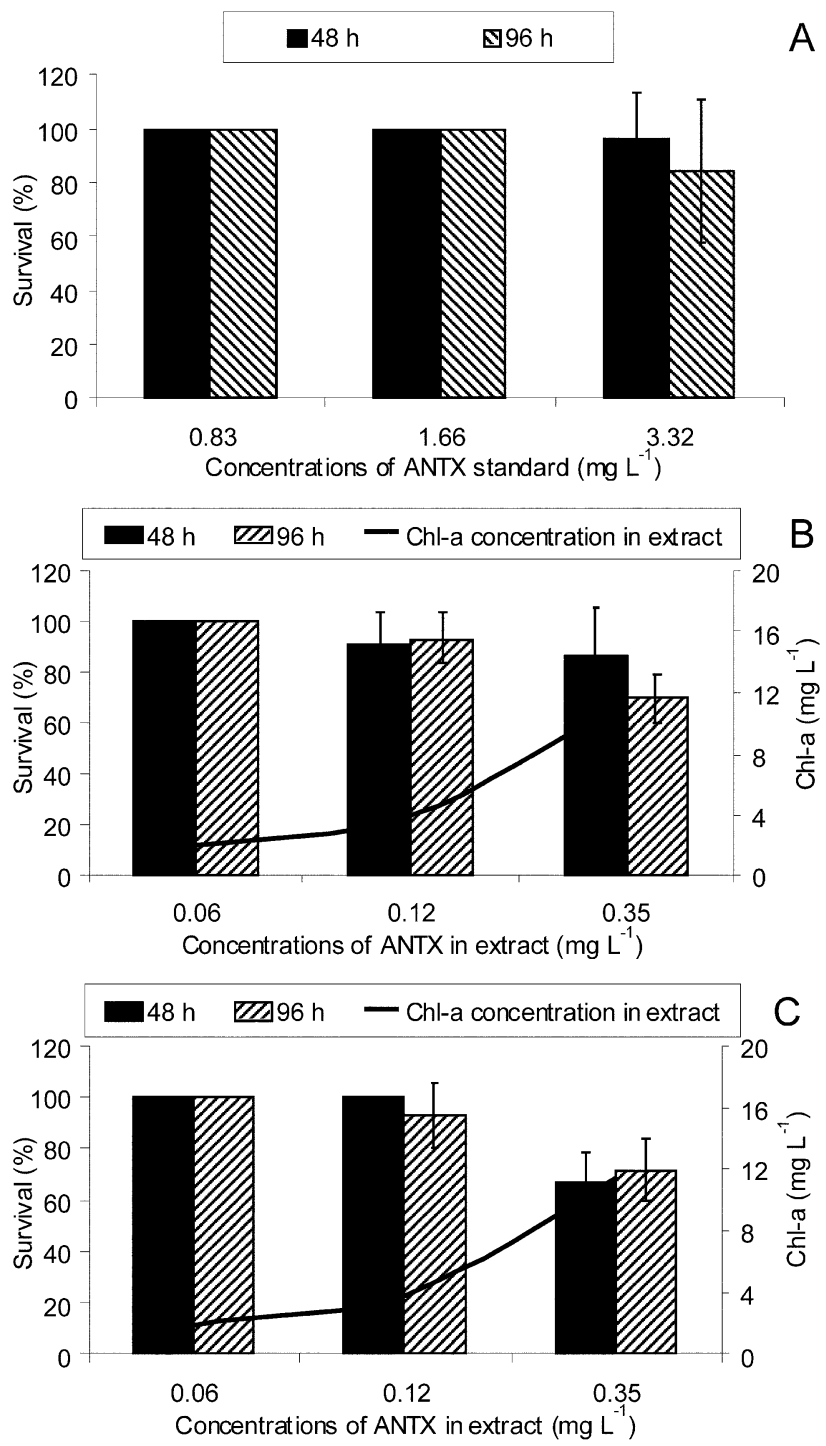

Fig. 5. Influence of pure ANTX (A) and D. lemmermannii extract containing different concentrations of $\operatorname{ANTX}(B, C)$ on survival of Chironomus spp. larvae after 48 and $96 \mathrm{~h}$ of exposure (mean values $\pm S D ; n=6$ ). Survival of organisms in controls was set as $100 \%$. A, B - riverine larvae, C - lake larvae.

some zoohydrobionts, particularly the benthic larvae of insects that are a very important component of aquatic food webs. Our study showed that in shallow eutrophicated reservoirs with a homogenous distribution of cyanobacteria and their toxins in the water, the Chironomus larvae may be affected by cyanotoxins contained in the cyanobacterial biomass, dissolved in the water and/or bound to bottom sediments. As reported by PawlikSkowrońska et al. $(2008,2010)$, microcystins were present in the lake in cell-bound, dissolved and sediment-bound forms. The surface layers of sediments $(1-7 \mathrm{~cm})$ in the Planktothrix-dominated Lake Syczyńskie were rich in microcystins $\left(0.91-0.13 \mu \mathrm{g}\right.$ MC-LR eq. $\mathrm{g}^{-1}$ D.W). ANTX produced by several species of Dolichospermum and Aphanizomenon can also bind to bottom sediments (e.g. 47-656 $\mu \mathrm{g}$ ANTX kg-1; Klitzke et al., 2011). This study revealed simultaneous accumulation of MCs and ANTX in benthic Chironomus sp. during 
multispecies water blooms formed by MC and/or ANTXproducing filamentous cyanobacteria. The lake larvae examined accumulated similar amounts of MCs (up to $20.1 \mu \mathrm{g} \mathrm{g}^{-1}$ D.W., mostly dm MC-RR), like the Chironomus sp. (up to $11.54 \mu \mathrm{g} \mathrm{MC-RR}$ and MC-LR g ${ }^{-1}$ D.W.) in the eutrophic Lake Chaohu (China) affected by blooms of Microcystis sp. and Dolichospermum sp. (Chen \& Xie, 2008). Currently there is no information on ANTX accumulation in insect larvae in their natural environments. Contents of ANTX in the larvae from Lake Syczyńskie were much higher than those of MCs despite the 1.5-20times higher concentrations of intracellular MCs in the lake water. Beside the planktonic, benthic cyanobacteria also can be an important source of ANTX. As reported by Aráoz et al. (2005), Oscillatoria formosa Bory and Oscillatoria sp. produce ANTX. Filaments of Oscillatoria limosa were found in the guts of Chironomus larvae from Lake Syczyńskie. The contents of cyanotoxins found in the benthic larvae seem to be a consequence of their high contents in the biomass of cyanobacteria, their main food (Ali, 1990; Frouz et al., 2004), and in the lake water. The highest amounts of MCs and ANTX were recorded in the spring population of Chironomus sp. inhabiting Lake Syczyńskie, which followed a period when $P$. agardhii overwintered on sediments, the development of a benthic mat of $O$. limosa and a mass development of $D$. flos-aque in the lake. In early spring, extracellular concentrations of cyanotoxins in water may also be high $(11 \mu \mathrm{g}$ eq. MC-LR $\mathrm{L}^{-1}$; Pawlik-Skowrońska et al., 2008) and may affect aquatic organisms. Beside the abundant cyanobacteria and species structure the life cycle of chironomids also seems to be a very important factor determining the accumulation of cyanotoxins in these organisms. The life cycle of Chironomus spp. (from egg to adult) can last from 12-14 days to more than a year, depending on the species and environmental conditions (Armiatge et al., 1995; Frouz et al., 2003; Kajak \& Prus, 2003). Hence, the observed differences in the cyanotoxin content in Chironomus larvae may depend on the duration of their development in the lake. Larvae of Chironomus spp. may be an important vector of both MCs and ANTX to organisms higher in the food chain. They are an essential prey of fish (Kajak \& Prus, 2003; Kornijów \& Pęczuła, 2005), in which the accumulation of cyanotoxins (Pawlik-Skowrońska et al., 2012) is also recorded.

Our experimental study also revealed that different populations of larvae (inhabiting the hypertrophic Lake Syczyńskie or a river free of cyanobacterial blooms) were resistant to high concentrations of extracellular MCs and ANTX contained in crude cyanobacterial extracts. The larvae used in this study could belong to different species. For example, in lakes and fish-ponds C. plumosus (L.) is the most abundant (Matěna, 1995, Panis et al., 1996) while in polluted rivers $C$. riparius Meigen is abundant (Groenendijk et al., 1998). Larval survival decreased when the cyanotoxin concentrations were much higher than those recorded in the lake. Altogether, this indicates that Chironomus larvae may possess some specific defence against cyanotoxins. Forcella et al. (2007) recorded an increase in specific enzymes, including glutathione-S-transferase, glutathione peroxidase and glutathione synthase, in Chironomus larvae under oxidative stress. Both MCs and ANTX cause oxidative stress in aquatic organisms (Blaha et al., 2004), and glutathione (GSH), a strong antioxidant, plays an essential role in coping with this stress. Glutathione-S-transferase conjugates microcystins with GSH to metabolise them into less harmful compounds (Pflugmacher et al., 1998), which can be physiologically degraded and excreted from cells. Detoxification of MCs under natural conditions takes several weeks and is dependent on many environmental and biological factors (Harada et al., 1996; Ozawa et al., 2003), animal species (Zhang et al., 2009) or phase of development (Oberemm et al., 1999). ANTX is decomposed to non-toxic dihydroanatoxin-a and epoxyanatoxin-a (Harada et al., 1993), and its half-life in water reservoirs is shorter than that of MCs (Hardy, 2008). In sediments, which are reached by very little light, the persistence of ANTX can be higher than in the lake water, because it undergoes rapid photochemical degradation in sunlight (Chorus \& Bartram, 1999). In spite of the lower stability of ANTX, it may be accumulated in benthic larvae. That is because, as reported previously in an experiment with fish (Kolmakov \& Gladyshew, 2003), MCs and/or ANTX-containing Nostocales (e.g. Dolichospermum flos-aquae, Aphanizomenon flos-aquae) were completely digested and assimilated. As reported by Ali (1990), filamentous cyanobacteria are an essential source of food for benthic insect larvae, and the abundance of $C$. crassicaudatus larvae increased with increase in abundance of cyanobacteria (Ali et al., 2002). In a laboratory feeding experiment larvae of the chironomid Glyptotendipes paripes Edwards were able to complete their development when fed on Lyngbya cf. aeruginosa Kütz. ex Gom. and Anabaena flos-aquae whereas those fed on Microcystis were smaller and many failed to complete their development (Frouz et al., 2004). The Chironomus larvae from Lake Syczyńskie also contained cyanobacteria in their guts, including among others $O$. limosa and $P$. agardhii. The high contents of ANTX and MCs recorded in the Chironomus sp. indicate a high probability of cyanotoxins being transfered to benthos-feeding and omnivorous fish. This creates potential human health risk.

The comparative bioassays of acute toxicity, carried out on the lake and riverine Chironomus larvae, revealed no clear differences in the resistance of the two populations to extracts of cyanobacteria containing extracellular MCs or ANTX. The cyanotoxins present in the larvae collected from the lake did not decrease their resistance to toxins. This may account for the existence of Chironomus larvae in water bodies affected by blooms of toxigenic cyanobacteria. Generally, both the larvae from the river and the lake were more resistant to pure MC-LR and ANTX than to extracts of cyanobacteria containing approximately 10times less MCs or ANTX. Some planktonic Dolichospermum spp. and benthic Anabaena species, in addition to ANTX may also produce other neurotoxins, like 
anatoxin-a(S) and cytotoxic oligopeptides (e.g. anabaenolysins; Jokela et al., 2012). Planktothrix spp., in addition to MCs may also produce other bioactive oligopeptides (e.g. aeruginosins 205a, -B 538, microviridins D-F), which have a negative effect on aquatic invertebrates (Shin et al., 1996; Blom et al., 2003). Moreover, the constituents of cyanobacterial extracts may have a synergistic effect or increase the uptake rate of anatoxin-a. The synergy between anatoxin-a and other cyanotoxins, such as microcystin-LR, is described for mice (Fitzgeorge et al., 1994). This may account for the stronger negative effect of crude cyanobacterial extracts. The resistance of Chironomus spp. living in the presence of cyanobacterial blooms and in a bloom-free ecosystem to high concentrations of cyanotoxins, however, may be due to their very high content of the antioxidant GSH and GSH/GSSG ratio (a biomarker of antioxidant potential). As stated by Forcella et al. (2007), Chironomus riparius Meigen contained 200-300 $\mathrm{m} \mathrm{GSH} \mathrm{g}^{-1}$ F.W. and the GSH/GSSG ratio was also high (23.7-28.8). The recently reported ability of daphnids to biodegrade MC by producing MC-GSH conjugates (Wojtal-Frankiewicz et al., 2013) indicates that it is likely that chironomid larvae, which also have a high GSH content, can quickly adapt to environmental threats such as cyanotoxins.

\section{CONCLUSIONS}

Larvae of Chironomus sp., inhabiting eutrophicated water bodies with multispecies blooms of toxigenic cyanobacteria, accumulate simultaneously both microcystins and anatoxin-a. The larvae, independent of their habitat, appeared to be very resistant to high concentrations of extracellular cyanotoxins and may be an important vector of both MCs and ANTX to organisms higher in the food chain.

ACKNOWLEDGEMENTS. This work was financially supported by The Polish Ministry of Science and Higher Education (grant No 304396636 to BPS). Thanks are expressed to $\mathrm{H}$. Mazur-Marzec for LC-MS identification of dmMC-RR and E. Słowikowska for her technical assistance. The authors would like to acknowledge the European Cooperation in Science and Technology, COST Action ES 1105 "CYANOCOST - Cyanobacterial blooms and toxins in water resources: Occurrence, impacts and management" for adding value to this study through networking and knowledge sharing with European experts and researchers in the field.

\section{REFERENCES}

Ali A. 1990: Seasonal changes of larval food and feeding of Chironomus crassicaudatus (Diptera: Chironomidae) in subtropical lake. - J. Am. Mosq. Control. Assoc. 6: 84-88.

Ali A., Frouz J. \& Lobinske R.J. 2002: Spatio-temporal effects of selected physico-chemical variables of water, algae and sediment chemistry on the larval community of nuisance Chironomidae (Diptera) in a natural and a man-made lake in central Florida. - Hydrobiologia 470: 181-193.

Armitage P.D., Cranston P.S. \& Pinder L.C.V. 1995: The Chironomidae: Biology and Ecology of Non-Biting Midges. Chapman and Hall, London, 572 pp.

Aroz R., NGhim H.O., Rippka R., Palibroda N., de Marsac N.T. \& Herdman M. 2005: Neurotoxins in axenic oscillatorian cya- nobacteria: coexistence of anatoxin-a and homoanatoxin-a determined by ligand-binding assay and GC/MS. - Microbiology 151: 1263-1273.

Bláha L., Kopp R., Šimková K. \& Mareš J. 2004: Oxidative stress biomarkers are modulated in silver carp (Hypophthalmichthys molitrix Val.) exposed to microcystin-producing cyanobacterial water bloom. - Acta Vet. Brno 73: 477-482.

Blom J.F., Bister B., Bischoff D., Nicholson G., Jung G., SüssMUTH R.D. \& JÜTTNER F. 2003: Oscillapeptin J, a new grazer toxin of the freshwater cyanobacterium Planktothrix rubescens. - J. Nat. Prod. 66: 431-434.

CARLSON R.E. 1977: A trophic state index for lakes. - Limnol. Oceanogr. 22: 361-369.

CARMichael W.W. 1992: Cyanobacteria secondary metabolites - the cyanotoxins. - J. Appl. Bacteriol. 72: 445-459.

Chen J. \& XIE P. 2008: Accumulation of hepatotoxic microcystins in freshwater mussels, aquatic insect larvae and Oligochaetes in a large, shallow eutrophic lake (Lake Chaohu) of subtropical China. - Fresen. Environ. Bull. 17: 849-854.

Chorus I. \& Bartram J. 1999: Toxic Cyanobacteria in Water: A Guide to their Public Health Consequences, Monitoring, and Management. E \& FN Spon., New York, 357 pp.

Ferrão-Filho A.S. \& Kozlowsky-Suzuki B. 2011: Cyanotoxins: bioaccumulation and effects on aquatic animals. - Mar. Drugs 9: 2729-2772.

Fitzgeorge R.B., Clark S.A. \& Kevil C.W. 1994: Routes of intoxication. In Codd G.A., Jeffries T.M., Keevil C.W. \& Potter E. (eds): Detection Methods for Cyanobacterial Toxins. The Royal Society of Chemistry, Cambridge, UK, pp. 69-74.

Forcella M., Berra E., Giacchini R. \& Parenti P. 2007: Antioxidant defenses preserve membrane transport activity in Chironomus riparius larvae exposed to anoxia. - Arch. Insect Biochem. Physiol. 65: 181-194.

Frouz J., Matěna J. \& Ali A. 2003: Survival strategies of chironomids (Diptera: Chironomidae) living in temporary habitats: a review. - Eur. J. Entomol. 100: 459-465.

Frouz J., Ali A. \& Lobinske R.J. 2004: Laboratory evaluation of six algal species for larval nutritional suitability of the pestiferous midge Glyptotendipes paripes (Diptera: Chironomidae). - J. Econ. Entomol. 97: 1884-1890.

Furey A., Crowley J., Hamilton B., Lehane M. \& James K.J. 2005: Strategies to avoid the misidentification of anatoxin-a using mass spectrometry in the forensic investigation of acute neurotoxic poisoning. - J. Chromat. (A) 1082: 91-97.

Golterman H.L. 1971: Methods for Chemical Analysis of Fresh Waters. Blackwell, Oxford, $166 \mathrm{pp}$.

GroenendiJk D., Postma J.F., Kraak M.H.S. \& Admiraal W. 1998: Seasonal dynamics and larval drift of Chironomus riparius (Diptera) in a metal contaminated lowland river. Aquat. Ecol. 32: 341-351.

Harada K.I., Nagai H., Kimura Y., Suzuki M., Park H.D., Watanabe M., LuUkKainen R., Sivonen K. \& Carmichael W.W. 1993: Liquid chromatography/mass spectrometric detection of anatoxin-a, a neurotoxin from cyanobacteria. Tetrahedron 49: 9251-9260.

Harada K.I., Tsuj K., Watanabe M.F. \& Kondo F. 1996: Stability of microcystins from cyanobacteria. III. Effect of $\mathrm{pH}$ and temperature. - Phycologia 35: 83-88.

HaRdy J. 2008: Final Report. Washington State Recreational Guidance for Microcystins (Provisional) and Anatoxin-a (Interim/Provisional). Washington State Department of Health, Olympia, WA, 19 pp.

Hašler P., PoulíčKovÁ A. \& Lysáková M. 2004: The survival and vitality of cyanobacteria and algae in fishpond bottom sediments. - Czech Phycol. (Olomouc) 4: 133-144. 
Ibelings B.W. \& HAVENS K.E. 2008: Cyanobacterial toxins: a qualitative meta-analysis of concentrations, dosage and effects in freshwater, estuarine and marine biota. In Kenneth H.H. (eds): Cyanobacterial Harmful Algal Blooms: State of the Science and Research Needs. 32. Springer, New York, pp. $675-732$

James K.J., Furey A., Sherlock I.R., Stack M.A. \& Twohing M. 1998: Sensitive determination of anatoxin-a, homoanatoxin-a and their degradation products by liquid chromatography with fluorometric detection. $-J$. Chromatogr. (A) 798: $147-157$.

Jokela J., Oftedal L., Herfindal L., Permi P., Wahlsten M., Døskeland S.O. \& Sivonen K. 2012: Anabaenolysins, novel cytolytic lipopeptides from benthic Anabaena cyanobacteria. PLOS One 7(7):e41222. DOI:10.1371/journal.pone.0041222.

KAJAK Z. \& Prus P. 2003: Seasonal and year-to-year variation of numbers of Chironomus plumosus L. and Tubificidae in a lowland reservoir: regularities, causes, mechanisms. - Pol. J. Ecol. 51: 339-351.

Klitzke S., Beusch C. \& Fastner J. 2011: Sorption of the cyanobacterial toxins cylindrospermopsin and anatoxin-a to sediments. - Water Res. 45: 1338-1346.

Kolmakov V. \& Gladyshev M. 2003: Growth and potential photosynthesis of cyanobacteria are stimulated by viable gut passage in crucian carp. - Aquat. Ecol. 37: 237-242.

KomÁREK J. 1996: Klíč k určování vodních květů sinic v České Republice. [Key to the identification of cyanobacterial waterblooms in Czech Republic.] In Maršálek B., Keršner V. \& Marvan P. (eds): Vodni květy sinic. [Cyanobacterial Waterblooms.] Nadatio Flos Aquae, Brno, pp. 22-85 [in Czech].

KomÁreK J. \& Anagnostidis K. 2005: Oscillatoriales. T 2. In Ettl H., Gärtner G., Gerloff J., Heyning H. \& Mollenhauer D. (eds): Süßwasserflora von Mitteleuropa. Spektrum Akademischer Verlag, Elsevier GmbH, München, 759 pp.

Korniów R. \& PęczuŁa W. 2005: Ecosystem of a small and shallow lake suffering from cyanobacterial blooms - hypertrophic, phytoplankton dominated or both? - Verh. Internat. Verein. Limnol. 29: 1015-1019.

Kotak B.G., Zurawell R.W., Prepas E.E. \& Holmes C.F.B. 1996: Microcystin-LR concentration in aquatic food web compartments from lakes of varying trophic status. - Can. J. Fish Aquat. Sci. 53: 1974-1985.

MatěNA J. 1995: Polymorphism of Chironomus plumosus (Diptera: Chironomidae) males from a temperate fish-pond population. - Eur. J. Entomol. 92: 699-703.

Mez K., Beattie K.A., Codd G.A., Hanselmann K., Hauser B., Naegeli H. \& Preisig H.R. 1997: Identification of a microcystin in benthic cyanobacteria linked to cattle deaths on alpine pastures in Switzerland. - Eur. J. Phycol. 32: 111-117.

Oberemm A., Becker J., Codd G.A. \& Steinberg C. 1999: Effects of cyanobacterial toxins and aqueous crude extracts of cyanobacteria on the development of fish and amphibians. Environ. Toxicol. 14: 77-88.

Osswald J., Rellán S., Carvalho A.P., Gago A. \& VasconCELOS V. 2007: Acute effects of an anatoxin-a producing cyanobacterium on juvenile fish - Cyprinus carpio L. - Toxicon 49: 693-698.

Ozawa K., Yokoyama A., Ishikawa K., Kumagai M., Watanabe M.F. \& PARK H.D. 2003: Accumulation and depuration of microcystin produced by the cyanobacterium Microcystis in a freshwater snail. - Limnology 4: 131-138.

Panis L.I., Goddeeris B. \& Verheyenl R. 1996: On the relationship between vertical microdistribution and adaptations to oxygen stress in littoral Chironomidae (Diptera). - Hydrobiologia 318: 61-67.

Pawlik-SkowrońsKa B., Pirszel J. \& Kornijów R. 2008: Spatial and temporal variation in microcystin concentrations during perennial bloom of Planktothrix agardhii in a hypertrophic lake. - Ann. Limnol. - Int. J. Lim. 44: 63-68.

Pawlik-Skowrońska B., Kornijów R. \& Pirszel J. 2010: Sedimentary imprint of cyanobacterial blooms - a new tool for insight into recent history of lakes. - Pol. J. Ecol. 58: 663-670.

Pawlik-Skowrońska B., Toporowska M. \& Rechulicz J. 2012: Simultaneous accumulation of anatoxin-a and microcystins in three fish species indigenous to lakes affected by cyanobacterial blooms. - Oceanol. Hydrobiol. Stud. 41(4): 53-65.

Pflugmacher S., Wiegand C., Oberemm A., Beattie K.A., Krause E. \& Codd G.A. 1998: Identification of an enzymatically formed glutathione conjugate of the cyanobacterial hepatotoxin microcystin-LR: the first step of detoxication. Biochim. Biophys. Acta 1425: 527-533.

PN-ISO 10260. 2002: Water Quality. Measurement of Biochemical Parameters. Spectrophotometric Determination of Chlorophyll-a. PWN, Warszawa, $11 \mathrm{pp}$.

Shin H.J., Murakami M., Matsuda H. \& Yamaguchi H. 1996: Microviridins D-F, serine protease inhibitors from the cyanobacterium Oscillatoria agardhii (NIES-204). — Tetrahedron 52: $8159-8168$

Sivonen K., Niemelä S.I., Niemi R.M., Lepistö L., Luoma T.H. \& RÄSÄNEN L.A. 1990: Toxic cyanobacteria (blue-green algae) in Finnish fresh and coastal waters. - Hydrobiologia 190: 267-275.

Toporowska M., Pawlik-Skowrońska B., Krupa D. \& Kornijów R. 2010: Winter versus summer blooming of phytoplankton in a shallow lake: effect of hypertrophic conditions. - Pol. J. Ecol. 58: 159-168.

UTERMÖHL H. 1958: Zur vervollkommung der quantitativen methodik. - Mitt. Int. Ver. Teor. Angew. Limnol. 9: 1-38.

Wacklin P., Hoffmann L. \& KomÁrek J. 2009: Nomenclatural validation of the genetically revised cyanobacterial genus Dolichospermum (Ralfs ex Bornet et Flahault) comb. nova. - Fottea 9(1): 59-64.

Welker M. \& DöHren H. 2006: Cyanobacterial peptides nature's own combinatorial biosynthesis. - FEMS Microbiol. Rev. 30: 530-563.

Wiederholm T. 1983: Chironomidae of the Holarctic region. Keys and diagnoses. Part 1. Larvae. - Entomol. Scand. (Suppl. 19), 538 pp.

Wojtal-Frankiewicz A., Bernasińska J., Jurczak T., GwoźDZiŃski K., Frankiewicz P. \& WielaneK M. 2013: Microcystin assimilation and detoxification by Daphnia spp. in two ecosystems of different cyanotoxin concentrations. - J. Limnol. 72: 154-171.

Zhang D., Xie P., Chen Y., Dai M., Qiu T., Liu Y. \& Liang G. 2009: Determination of microcystin-LR and its metabolites in snail (Bellemya aeruginosa), shrimp (Macrobrachium nipponensis) and silver carp (Hypophthalmichthys molitrix) from lake Taihu, China. - Chemosphere 76: 974-981.

Received March 22, 2013, revised and accepted July 1, 2013 